Zeszyty Naukowe Szkoły Głównej Gospodarstwa Wiejskiego w Warszawie

Problemy Rolnictwa Światowego tom 18 (XXXIII), zeszyt 3, 2018: 248-261

DOI: $10.22630 /$ PRS.2018.18.3.83

Karolina Pawlak $^{1}$

Uniwersytet Przyrodniczy w Poznaniu

\title{
Zdolność konkurencyjna przemysłu spożywczego krajów UE, USA i Kanady na rynku światowym ${ }^{2}$
}

\section{Competitive Capacity of the EU, the US and Canadian Food Industry on the World Market}

\begin{abstract}
Synopsis. Celem artykułu była ocena zdolności konkurencyjnej głównych branż przemysłu spożywczego UE, USA i Kanady na rynku światowym, z wykorzystaniem wybranych wskaźników ekonomicznych i handlowych. Zakres czasowy analiz objął lata 2007-2016. W badaniach wykorzystano dane urzędów i agencji statystycznych UE (Eurostat), USA (US Census Bureau, FAS/USDA) i Kanady (Agriculture and Agri-food Canada). Na podstawie przeprowadzonych analiz można stwierdzić, że poprawa pozycji konkurencyjnej branż unijnego przemysłu spożywczego w większym stopniu była determinowana skalą aktywności w handlu światowym (rosnącymi udziałami w globalnym eksporcie), natomiast o przewagach konkurencyjnych przemysłu spożywczego USA i Kanady decydowały przewagi o charakterze ekonomicznym, związane z poprawą ekonomicznych wyników działalności przedsiębiorstw danej branży, jej udziału w tworzeniu realnej wartości dodanej przemysłu spożywczego oraz produktywności pracy.
\end{abstract}

Słowa kluczowe: konkurencyjność, przemysł spożywczy, relatywna przewaga w handlu, realna wartość dodana, realna produktywność pracy, UE, USA, Kanada

\begin{abstract}
The aim of the paper was to assess the competitive capacity of the main sectors of the EU, the US and Canadian food industry, using selected economic and trade indicators. Time range of the research covered the years 2007-2016. The research is based on the data from the Statistical Office of the European Union (Eurostat), the US Census Bureau, the USDA Foreign Agricultural Service's Global Agricultural Trade System (FAS/USDA) and Agriculture and Agri-food Canada. It was proved that improvement of the competitive position of the EU food industry was more determined by the scale of activity in world trade (increasing share in global exports), while competitive advantages of the US and Canadian food industry were influenced by economic advantages associated with improving the economic performance of enterprises in a given sector, its share in the real value added of the food industry as a whole and labour productivity.
\end{abstract}

Key words: competitiveness, food industry, relative trade advantage, real value added, real labour productivity, the EU, the US, Canada

JEL Classification: F14, L66, Q13

${ }^{1}$ dr hab., prof. nadzw., Katedra Ekonomii i Polityki Gospodarczej w Agrobiznesie,

Wydział Ekonomiczno-Społeczny, Uniwersytet Przyrodniczy w Poznaniu, ul. Wojska Polskiego 28, 60-637 Poznań, e-mail: pawlak@up.poznan.pl, https://orcid.org/0000-0002-5441-6381

2 Artykuł współfinansowany przez Narodowe Centrum Nauki ze środków na naukę w ramach projektu badawczego z zakresu badań podstawowych OPUS nr 2015/17/B/HS4/00262, pt. Polski sektor rolnożywnościowy w warunkach implementacji Umowy o Transatlantyckim Partnerstwie Handlowym i Inwestycyjnym (TTIP). 


\section{Wprowadzenie}

Przetwórstwo żywności i napojów jest strategiczną branżą każdej gospodarki, nie tylko ze względu na charakter wytwarzanych w nim dóbr i zaspokajanie popytu na żywność, ale także $\mathrm{z}$ uwagi na istotną rolę $\mathrm{w}$ tworzeniu produktu krajowego brutto, kształtowaniu rynku pracy oraz w wymianie międzynarodowej (por. Poczta i Beba, 2014). Przemysł spożywczy w UE jest ważnym sektorem gospodarki. W 2015 roku w ponad 265 tys. przedsiębiorstw przemysłu spożywczego zatrudnienie znajdowało $3,8 \mathrm{mln}$ osób, tj. blisko 13,5\% ogółu zatrudnionych w przetwórstwie przemysłowym. Wytwarzali oni produkcję o wartości 880 mld euro i wartość dodaną (w cenach czynników produkcji) rzędu 190 mld euro, co stanowiło odpowiednio 13\% produkcji i 10\% wartości dodanej przetwórstwa przemysłowego ogółem (Eurostat, 2018). Można jednak przypuszczać, że z jednej strony, w warunkach ograniczonego wzrostu popytu na żywność w UE, a z drugiej wobec silnej koncentracji obrotów handlowych w obszarze Jednolitego Rynku Europejskiego, dalszy rozwój tego sektora gospodarki UE w dużej mierze będzie zależał od możliwości rozszerzenia zbytu na rynki pozaunijne. Skuteczne lokowanie wytwarzanych produktów zarówno na rynkach UE, jak i na rynkach zagranicznych będzie natomiast wymagało sprostania presji konkurencyjnej ze strony innych dostawców żywności.

Funkcjonujące symultanicznie mechanizmy współpracy i rywalizacji $\mathrm{w}$ wielu dziedzinach życia społeczno-gospodarczego, w tym w sferze polityki zagranicznej i handlu, cechują między innymi stosunki transatlantyckie ${ }^{3}$. Kraje UE i USA, a w mniejszym zakresie także Kanada, są dla siebie nawzajem ważnymi partnerami gospodarczymi, a zarazem konkurentami na rynkach międzynarodowych. Wyrazem dążenia do pogłębienia wzajemnych relacji gospodarczych, a przez to utrzymania silnej pozycji tych państw na rynku międzynarodowym, szczególnie wobec rosnącego znaczenia politycznego i dużego potencjału gospodarczego krajów BRICS (Gradziuk i Kugiel, red., 2012; The BRICS Report, 2012; Sporek i Czech, red., 2015; Nassif, Feijo i Araújo, 2016; Nayyar, 2016; Siddiqui, 2016), są zawarte Całościowe Gospodarcze i Handlowe Porozumienie UEKanada (EU-Canada Comprehensive Economic and Trade Agreement - CETA) oraz negocjowane do tej pory bezskutecznie Transatlantyckie Partnerstwo HandlowoInwestycyjne (The Transatlantic Trade and Investment Partnership - TTIP). W kontekście narastających problemów w stosunkach transatlantyckich, szczególnie w relacjach UEUSA w okresie prezydentury Donalda Trumpa, a zwłaszcza po jego zapowiedzi podniesienia ceł na stal i aluminium w marcu 2018 roku (Kiwerska, 2018), kwestia konkurencyjności gospodarek tych trzech partnerów handlowych w układzie bilateralnym i na rynku światowym nabiera szczególnego znaczenia.

Poza zgodą co do tego, że konkurencyjność jest pojęciem relatywnym, wartościującym i określającym pewien stan pożądany, w licznych definicjach konkurencyjności ujawnia się jej wielowymiarowość. Przez różne dyscypliny naukowe jest ona rozpatrywana $\mathrm{z}$ różnych punktów widzenia, w różnym horyzoncie czasowym, przy zróżnicowanym poziomie agregacji i z położeniem nacisku na aspekty istotne dla danej dyscypliny (zob. np. Porter, 1990; Siggel, 2006; Latruffe, 2010; Pawlak, 2013). Wielość funkcjonujących definicji konkurencyjności wynika też z możliwości wyprowadzenia tej kategorii pojęciowej z przynajmniej kilku teorii ekonomii, w tym przede wszystkim z teorii wzrostu gospodarczego i handlu międzynarodowego.

\footnotetext{
${ }^{3}$ Szerzej na ten temat zob. Milczarek (2008).
} 
Nurt badań konkurencyjności oparty na teorii wzrostu gospodarczego akcentuje ogólne lub odcinkowe wyniki osiagane przez gospodarkę narodową. Konkurencyjność gospodarki jest tu określna jako „zdolność kraju do wytwarzania dóbr i usług, które w warunkach wolnego i uczciwego handlu są akceptowane na rynku światowym, a więc są konkurencyjne w stosunku do towarów i usług produkowanych w innych krajach, przy jednoczesnym wzroście dochodów realnych ludności" (President's Commission on Industrial Competitiveness, 1985). W tym ujęciu do pomiaru konkurencyjności wykorzystywane są typowe mierniki wzrostu gospodarczego, co pośrednio wskazuje na wpływ polityki ekonomicznej państwa na poziom i zmiany konkurencyjności (Jagiełło, 2008). Tempo wzrostu produktywności krajowej za kluczowe $\mathrm{w}$ definiowaniu konkurencyjności uznali Krugman (1994) i Fagerberg (1996). Ten ostatni w sposób szczególny podkreślał, że należy to pojęcie rozpatrywać w kategoriach względnych, a oceniając poziom konkurencyjności należy posługiwać się relatywnymi, a nie absolutnymi wskaźnikami wzrostu gospodarczego. Fagerberg (1996) wskazywał również, że celem konkurencyjnej gospodarki $\mathrm{z}$ jednej strony jest zapewnienie dobrobytu ekonomicznego ludności, a $\mathrm{z}$ drugiej rozwój wymiany międzynarodowej. Idee konkurencyjności Fagerberga (1997) rozszerzył Aiginger (1998), który dowodził, że konkurencyjność to zdolność sprzedaży wystarczającej dla zachowania równowagi zewnętrznej ilości dóbr i usług, a także zapewnienia oczekiwanego (zgodnego z bieżącymi i zmieniającymi się aspiracjami narodowymi) wzrostu dochodów z czynników produkcji oraz satysfakcjonujących społeczeństwo warunków socjoekonomicznych i środowiskowych.

Zbliżoną do definicji konkurencyjności gospodarki krajowej Fagerberga (1997), ale w odniesieniu do jej sektora (a więc na poziomie mezoekonomicznym), sformułował Devine (1996) za Singh (1977). Według tych autorów wydajny, czyli konkurencyjny sektor to taki, który jest zdolny nie tylko zaspokajać popyt na rynku krajowym, ale także na rynkach zagranicznych, czerpiąc $\mathrm{z}$ tego tytułu środki na pokrycie niezbędnych wydatków importowych, przy utrzymaniu społecznie akceptowanego poziomu produkcji, zatrudnienia i kursu wymiany. Te definicje można uznać za definicje z pogranicza nurtu wzrostu gospodarczego i handlu międzynarodowego, w którym o konkurencyjności mówi się jako o zdolności do utrzymania lub powiększenia udziałów rynkowych (van Duren, Martin i Westgren, 1991; Kennedy i in. 1997; Pitts i Lagnevik 1998; Fischer i Schornberg, 2007). Konkurencyjność przemysłu spożywczego i jego poszczególnych branż można także zdefiniować jako trwała zdolność do generowania zysku oraz utrzymywania udziałów w rynku krajowym i rynkach eksportowych, na których badane branże są aktywne (Wijnands i in., 2008; Wijnands, van Berkum i Verhoog, 2015). Jest to zgodne z poglądem Krugmana (1994), który wskazuje, że pomiar konkurencyjności na rynkach zagranicznych nie ma większego sensu, jeśli działalność danego przemysłu koncentruje się niemal wyłącznie na rynku krajowym.

Podsumowując powyższe rozważania należy zauważyć, że jednoznaczny podział definicji konkurencyjności pomiędzy oba wspomniane nurty teoretyczne nie jest możliwy. $\mathrm{Z}$ jednej strony, pozycja kraju w gospodarce światowej zależy od stanu całej gospodarki, a z drugiej - wszystkie współczesne teorie wzrostu uwzględniają konsekwencje zaangażowania się kraju $\mathrm{w}$ międzynarodowym podziale pracy (zob. Lubiński, 1995; Fagerberg, Knell i Srholec, 2004). Stąd, celem artykułu jest ocena zdolności konkurencyjnej głównych branż przemysłu spożywczego UE, USA i Kanady na rynku światowym, z wykorzystaniem wybranych wskaźników ekonomicznych i handlowych. 


\section{Dane i metody}

Biorąc pod uwagę omówione powyżej, „podwójne” znaczenie pojęcia konkurencyjności, dla oszacowania zdolności konkurencyjnej wybranych branż przemysłu spożywczego zastosowano zestaw wskaźników wywodzących się zarówno z handlowego, jak i wzrostowego nurtu badań nad konkurencyjnością. Opierając się na podejściu metodycznym zaproponowanym przez Wijnandsa, van der Meulen i Poppe (2006), spośród wskaźników bazujących na udziałach w rynku i handlu wykorzystano: udziały w eksporcie światowym i wskaźniki relatywnej przewagi w handlu, a spośród wskaźników ekonomicznych posłużono się: realną wartością dodaną i jej udziałem w wartości dodanej sektora oraz realną produktywnością pracy ${ }^{4}$.

Udział w eksporcie światowym jest najprostszą miarą pozycji konkurencyjnej danego kraju lub sektora na rynku światowym. Najczęściej przyjmuje się, że jeśli udział danego kraju w eksporcie światowym nie ulega zmianie lub rośnie, jego międzynarodowa pozycja konkurencyjna utrzymuje się lub umacnia (Zawiślińska, 2003).

Indeks relatywnej przewagi w handlu (Relative Trade Advantage Index - RTA), będac różnicą wskaźników ujawnionych przewag komparatywnych w eksporcie (Relative Export Advantage Index - RXA) i imporcie (Relative Import Advantage Index - RMA), umożliwia oszacowanie przewag komparatywnych, $\mathrm{z}$ uwzględnieniem jednocześnie sytuacji importowej i eksportowej danego kraju. Pierwszy z nich stanowi relację udziału eksportu analizowanego produktu w eksporcie światowym/regionalnym do udziału eksportu całego sektora w eksporcie światowym/regionalnym, a drugi wyznacza się w sposób analogiczny dla importu (Scott i Vollrath, 1992):

$$
\begin{aligned}
\operatorname{RXA}_{\mathrm{ij}} & =\left(\mathrm{X}_{\mathrm{ij}} / \mathrm{X}_{\mathrm{nj}}\right) /\left(\mathrm{X}_{\mathrm{ik}} / \mathrm{X}_{\mathrm{nk}}\right) \\
\mathrm{RMA}_{\mathrm{ij}} & =\left(\mathrm{M}_{\mathrm{ij}} / \mathrm{M}_{\mathrm{nj}}\right) /\left(\mathrm{M}_{\mathrm{ik}} / \mathrm{M}_{\mathrm{nk}}\right)
\end{aligned}
$$

gdzie: $X$ - eksport, $M$ - import, $i$ - badany kraj, $j$ - analizowany produkt/grupa produktów, $k$ - wszystkie towary, $n-\mathrm{kraj} / \mathrm{kraje}$ odniesienia.

Dodatnia wartość wskaźnika RTA wskazuje na przewagę konkurencyjną, a ujemna na odpowiednio niekorzystną sytuację konkurencyjną (Frohberg i Hartmann, 1997).

Realna wartość dodana (Real Value Added - RVA; w cenach czynników wytwórczych) ilustruje przyrost wartości dóbr w wyniku procesu produkcji i odzwierciedla pozycję konkurencyjną przemysłu spożywczego i jego branż na rynku krajowym:

$$
\mathrm{RVA}_{\mathrm{ij}}=\mathrm{VA}_{\mathrm{ij}} / \mathrm{CP}_{\mathrm{i}}
$$

gdzie: $V A$ - nominalna wartość dodana, $i$ - badany kraj, $j$ - analizowana branża przemysłu spożywczego, $C P$ - wskaźnik cen konsumpcyjnych.

\footnotetext{
${ }^{4}$ Identyczny zestaw wskaźników w badaniach konkurencyjności przemysłu spożywczego UE na tle USA, Australii, Brazylii i Kanady zastosowali Wijnands i Verhoog (2016). Konkurencyjność szwajcarskiego przemysłu spożywczego względem wybranych państw UE-15 zbadali w ten sposób Wijnands, van Berkum i Verhoog (2015), a polskiego - Tereszczuk (2016).
} 
Jednym z kluczowych determinantów konkurencyjności jest $\mathrm{z}$ kolei produktywność pracy (Real Labour Productivity - RLP), informująca o wartości realnej wartości dodanej wytworzonej przez 1 zatrudnionego w badanej branży:

$$
\operatorname{RLP}_{\mathrm{ij}}=\mathrm{RVA}_{\mathrm{ij}} / \mathrm{E}_{\mathrm{ij}}
$$

gdzie: $E$ - liczba zatrudnionych w analizowanej branży przemysłu spożywczego.

Znaczenie analizowanej branży na tle pozostałych branż przemysłu spożywczego oceniono na podstawie udziałów poszczególnych branż w realnej wartości dodanej całego sektora (Real Value Added Share - SRVA):

$$
\mathrm{SRVA}_{\mathrm{ij}}=\mathrm{RVA}_{\mathrm{ij}} / \mathrm{RVA}_{\mathrm{im}}
$$

gdzie: $m$ - przemysł spożywczy (jako całość).

Odwołując się do dynamicznego ujęcia konkurencyjności przemysłu spożywczego jako długofalowej zdolności do utrzymania lub zwiększenia posiadanych udziałów w rynku krajowym i światowym, ocenę zmian poziomu konkurencyjności oparto na zmianach wartości wymienionych wskaźników w skrajnych latach dwóch okresów badawczych (2007-2011 i 2012-2016). Zmiany wskaźników handlowych wyznaczono w sensie absolutnym, w punktach procentowych, natomiast w przypadku wskaźników ekonomicznych zastosowano wskaźniki dynamiki. Dla ułatwienia porównań wszystkie wskaźniki poddano standaryzacji zgodnie ze wzorem:

z-score $=($ wskaźnik niestandaryzowany - średnia arytmetyczna wskaźników dla badanych krajów) / odchylenie standardowe

Następnie wyznaczono syntetyczną miarę konkurencyjności, będącą średnią arytmetyczną pięciu wykorzystanych wskaźników cząstkowych, która w sposób całościowy ilustruje pozycję konkurencyjną analizowanego kraju $\mathrm{w}$ danej branży przemysłu spożywczego względem pozostałych państw stanowiących punkt odniesienia. Wartości wskaźników $\mathrm{z}$-score osiagają wartości niemianowane $\mathrm{z}$ przedziału [-2;2], posiadają średnią 0 i odchylenie standardowe 1 .

Analizę wykonano dla czterech branż przemysłu spożywczego o dużym znaczeniu zarówno $\mathrm{w}$ handlu międzynarodowym, jak i udziale w przetwórstwie przemysłowym, tj.: mleczarskiej (NACE C105 i NAICS 3115), mięsnej (NACE C101 i NAICS 3116), owocowo-warzywnej (NACE C103 i NAICS 3114) i cukierniczej (NACE C1082 i NAICS 3113, z wyłączeniem NAICS 31131), wyodrębnionych zgodnie ze statystyczną klasyfikacją działalności gospodarczej w UE (NACE Rev.2) oraz Ameryce Północnej (NAICS). W obu klasyfikacjach przemysł spożywczy jest rozumiany jako produkcja artykułów spożywczych, z wyłączeniem napojów i wyrobów tytoniowych (dział NACE C10 i NAICS 311). W badaniach wykorzystano dane Urzędu Statystycznego Unii Europejskiej (Eurostat), agencji statystycznej Departamentu Handlu Stanów Zjednoczonych (US Census Bureau), Global Agricultural Trade System pod nadzorem służb zagranicznych Departamentu Rolnictwa Stanów Zjednoczonych (FAS/USDA) oraz Agriculture and Agrifood Canada. W odniesieniu do krajów UE przyjęto wartości obrotów handlowych realizowanych z krajami spoza UE. Zakres czasowy analiz objął lata 2007-2016, z podziałem na dwa okresy badawcze: 2007-2011 i 2012-2016. 


\section{Ocena zmian konkurencyjności wybranych branż przemysłu spożywczego krajów UE, USA i Kanady w latach 2007-2011 i 2012-2016}

W latach 2012-2016 kraje UE dostarczały na rynek światowy niemal 15\% całości eksportu artykułów mleczarskich, generując $\mathrm{w}$ ich wywozie najwyższe spośród czterech badanych grup produktów i wyższe niż pozostałe dwa kraje przewagi komparatywne (RTA=1,25; tab. 1). Pozycja konkurencyjna amerykańskiego przemysłu mleczarskiego na rynku światowym, mierzona zarówno udziałem w rynku, jak i poziomem przewag komparatywnych, była słabsza niż państw UE, przy porównywalnym znaczeniu tej branży przemysłu spożywczego $\mathrm{w}$ tworzeniu realnej wartości dodanej przemysłu spożywczego w tych krajach (ponad 11\%). Większy udział w generowaniu nowo wytwarzanej wartości w przemyśle spożywczym miała branża mleczarska w Kanadzie (niemal 13,5\%), jednak kraj ten nie należał do znaczących światowych eksporterów tej grupy asortymentowej i nie uzyskiwał $\mathrm{w}$ ich wywozie przewag komparatywnych. Mankamentem przemysłu mleczarskiego UE była niska wydajność pracy - ponad 2-krotnie niższa niż w Kanadzie i 3,5-krotnie niższa niż w USA. Przeprowadzona syntetyczna ocena konkurencyjności (O) wykazała, że w latach 2007-2016 zdolność konkurencyjna branży mleczarskiej UE i USA ulegała systematycznemu osłabieniu, a Kanady umacniała się (rys. 1) ${ }^{5}$. W latach 20122016, w porównaniu z dwoma pozostałymi państwami, konkurencyjność unijnego przemysłu mleczarskiego ukształtowała się poniżej przeciętnej, głównie za sprawą znacznego obniżenia produktywności pracy (L) i udziału branży w generowaniu realnej wartości dodanej przemysłu spożywczego (S). Podobne kierunkowo tendencje, ale o mniejszej dynamice, obserwowano w USA, które dodatkowo, w przeciwieństwie do UE, traciły udziały weksporcie światowym. Kanadyjska branża mleczarska wzmacniała w badanym okresie swą pozycję konkurencyjna, szczególnie rozpatrywaną przez pryzmat wskaźników ekonomicznych. Mniej dynamiczne były zmiany jej pozycji handlowej.

Drugą branżą przemysłu spożywczego UE, która odznaczała się przewagami komparatywnymi na rynku światowym było przetwórstwo owocowo-warzywne. Poziom przewag $(\mathrm{RTA}=0,25)$ generowanych $\mathrm{w}$ latach $2012-2016$ był co prawda niższy niż w eksporcie produktów mleczarskich, ale w porównaniu z dwoma pozostałymi państwami, które takich przewag nie uzyskiwały w ogóle $(\mathrm{RTA}<0)$, pozycja konkurencyjna UE była stosunkowo najsilniejsza (tab. 1). Co istotne, państwa UE posiadały również najwyższy, niemal 10-procentowy udział w eksporcie światowym. Mniej korzystnie kształtowała się sytuacja konkurencyjna tej branży unijnego przemysłu spożywczego, mierzona wartością wskaźników ekonomicznych. Zarówno udział w tworzeniu realnej wartości dodanej całego sektora, jak i produktywność pracy w przedsiębiorstwach branży mleczarskiej były w UE niższe niż w USA i Kanadzie. W perspektywie długofalowej niepokojące jest osłabienie przewag konkurencyjnych przemysłu owocowo-warzywnego UE na rynku światowym (rys. 2). W latach 2012-2016 przewagi unijnego przetwórstwa owocowo-warzywnego na tle konkurentów nadal osiągały poziom ponadprzeciętny, ale były niższe niż uzyskiwane przez USA. Ponadto, o ile przewagi $\mathrm{w}$ handlu $(\mathrm{T})$ i ekonomiczne wskaźniki konkurencyjności (P, S, L) amerykańskiego przemysłu owocowo-warzywnego ulegały systematycznej

poprawie,

\footnotetext{
${ }^{5}$ Stanowiło to przełamanie przeciwnych kierunkowo tendencji obserwowanych w latach 2007-2012 w porównaniu z okresem 2003-2007 (zob. Wijnands i Verhoog, 2016).
} 
Tabela 1. Konkurencyjność wybranych branż przemysłu spożywczego w krajach UE, USA i Kanadzie w latach 2007-2016

Table 1. Competitiveness of the selected sectors of the EU, the US and Canadian food industry in 2007-2016

\begin{tabular}{|c|c|c|c|c|c|c|c|c|c|}
\hline \multirow[b]{2}{*}{ Wskaźnik } & \multicolumn{3}{|c|}{ Kanada } & \multicolumn{3}{|c|}{ UE } & \multicolumn{3}{|c|}{ USA } \\
\hline & $\begin{array}{l}2007- \\
2011\end{array}$ & $\begin{array}{l}2012- \\
2016\end{array}$ & Zmiana $^{\mathrm{a}}$ & $\begin{array}{l}2007- \\
2011\end{array}$ & $\begin{array}{l}2012- \\
2016\end{array}$ & Zmiana $^{a}$ & $\begin{array}{l}2007- \\
2011\end{array}$ & $\begin{array}{l}2012- \\
2016\end{array}$ & Zmiana $^{\mathrm{a}}$ \\
\hline & \multicolumn{9}{|c|}{ Branża mleczarska } \\
\hline $\begin{array}{l}\text { Udział w eksporcie } \\
\text { światowym (MS; \%) }\end{array}$ & 0,41 & 0,39 & $-0,02$ & 13,79 & 14,79 & 1,00 & 4,41 & 5,88 & 1,47 \\
\hline $\begin{array}{l}\text { Wskaźnik relatywnej } \\
\text { przewagi w handlu (RTA) }\end{array}$ & $-0,18$ & $-0,18$ & 0,00 & 1,20 & 1,25 & 0,05 & 0,12 & 0,26 & 0,14 \\
\hline $\begin{array}{l}\text { Realna wartość dodana } \\
\text { (mld USD) }\end{array}$ & 3,38 & 3,83 & 113,35 & 25,04 & 24,38 & 97,37 & 28,61 & 31,48 & 110,02 \\
\hline $\begin{array}{l}\text { Udział realnej wartości } \\
\text { dodanej w wartości dodanej } \\
\text { przemysłu spożywczego } \\
\text { ogółem }(\%)\end{array}$ & 12,95 & 13,37 & 103,27 & 11,30 & 11,10 & 98,25 & 11,48 & 11,61 & 101,12 \\
\hline \multirow[t]{2}{*}{$\begin{array}{l}\text { Produktywność pracy (mln } \\
\text { USD/zatrudnionego) }\end{array}$} & 0,15 & 0,16 & 109,20 & 0,07 & 0,07 & 95,20 & 0,22 & 0,24 & 110,19 \\
\hline & \multicolumn{9}{|c|}{ Branża mięsna } \\
\hline $\begin{array}{l}\text { Udział w eksporcie } \\
\text { światowym (MS; \%) }\end{array}$ & 1,59 & 1,75 & 0,16 & 4,37 & 4,16 & $-0,21$ & 4,20 & 4,75 & 0,55 \\
\hline $\begin{array}{l}\text { Wskaźnik relatywnej } \\
\text { przewagi w handlu (RTA) }\end{array}$ & $-0,70$ & $-0,81$ & $-0,11$ & $-1,04$ & $-1,04$ & 0,00 & $-0,85$ & $-0,69$ & 0,16 \\
\hline $\begin{array}{l}\text { Realna wartość dodana } \\
\text { (mld USD) }\end{array}$ & 6,03 & 6,57 & 109,01 & 40,87 & 39,89 & 97,59 & 51,43 & 57,10 & 111,02 \\
\hline $\begin{array}{l}\text { Udział realnej wartości } \\
\text { dodanej w wartości dodanej } \\
\text { przemysłu spożywczego } \\
\text { ogółem }(\%)\end{array}$ & 23,11 & 22,95 & 99,32 & 18,44 & 18,16 & 98,48 & 20,65 & 21,07 & 102,03 \\
\hline \multirow[t]{2}{*}{$\begin{array}{l}\text { Produktywność pracy (mln } \\
\text { USD/zatrudnionego) }\end{array}$} & 0,09 & 0,11 & 119,75 & 0,05 & 0,04 & 97,70 & 0,10 & 0,12 & 114,89 \\
\hline & \multicolumn{9}{|c|}{ Branża owocowo-warzywna } \\
\hline $\begin{array}{l}\text { Udział w eksporcie } \\
\text { światowym (MS; \%) }\end{array}$ & 2,64 & 2,61 & $-0,03$ & 9,07 & 9,68 & 0,61 & 7,61 & 8,72 & 1,11 \\
\hline $\begin{array}{l}\text { Wskaźnik relatywnej } \\
\text { przewagi w handlu (RTA) }\end{array}$ & $-0,70$ & $-0,84$ & $-0,14$ & $-0,23$ & 0,25 & 0,48 & $-0,70$ & $-0,54$ & 0,16 \\
\hline $\begin{array}{l}\text { Realna wartość dodana } \\
\text { (mld USD) }\end{array}$ & 2,55 & 2,74 & 107,46 & 16,81 & 16,95 & 100,81 & 28,65 & 32,53 & 113,55 \\
\hline $\begin{array}{l}\text { Udział realnej wartości } \\
\text { dodanej w wartości dodanej } \\
\text { przemysłu spożywczego } \\
\text { ogółem }(\%)\end{array}$ & 9,78 & 9,58 & 97,91 & 7,59 & 7,72 & 101,73 & 11,50 & 12,00 & 104,37 \\
\hline $\begin{array}{l}\text { Produktywność pracy (mln } \\
\text { USD/zatrudnionego) }\end{array}$ & 0,12 & 0,14 & 114,41 & 0,07 & 0,07 & 98,91 & 0,17 & 0,20 & 118,03 \\
\hline & \multicolumn{9}{|c|}{ Branża cukiernicza } \\
\hline $\begin{array}{l}\text { Udział w eksporcie } \\
\text { światowym (MS; \%) }\end{array}$ & 2,18 & 2,08 & $-0,10$ & 6,26 & 5,82 & $-0,44$ & 4,23 & 4,99 & 0,76 \\
\hline $\begin{array}{l}\text { Wskaźnik relatywnej } \\
\text { przewagi w handlu (RTA) }\end{array}$ & $-0,39$ & $-0,39$ & 0,00 & 0,00 & $-0,09$ & $-0,09$ & $-0,59$ & $-0,50$ & 0,09 \\
\hline $\begin{array}{l}\text { Realna wartość dodana } \\
\text { (mld USD) }\end{array}$ & 1,45 & 1,50 & 103,20 & 15,25 & 14,13 & 92,65 & 13,80 & 15,34 & 111,11 \\
\hline $\begin{array}{l}\text { Udział realnej wartości } \\
\text { dodanej w wartości dodanej } \\
\text { przemysłu spożywczego } \\
\text { ogółem }(\%)\end{array}$ & 5,57 & 5,24 & 94,03 & 6,88 & 6,43 & 93,49 & 5,54 & 5,66 & 102,12 \\
\hline $\begin{array}{l}\text { Produktywność pracy (mln } \\
\text { USD/zatrudnionego) }\end{array}$ & 0,15 & 0,16 & 109,15 & 0,08 & 0,08 & 93,30 & 0,21 & 0,22 & 105,64 \\
\hline
\end{tabular}

a - zgodnie z przyjętym podejściem metodycznym, zmiany wskaźników handlowych (udziały w eksporcie światowym i wskaźniki relatywnych przewag w handlu) wyznaczono w sensie absolutnym, w punktach procentowych, natomiast w przypadku wskaźników ekonomicznych (realna wartość dodana i jej udział w wartości dodanej przemysłu spożywczego ogółem oraz realna produktywność pracy) zastosowano miary dynamiki

Źródło: (Agriculture and Agri-Food Canada 2018; Eurostat 2018; GATS 2018; The US Census Bureau 2018), obliczenia własne. 


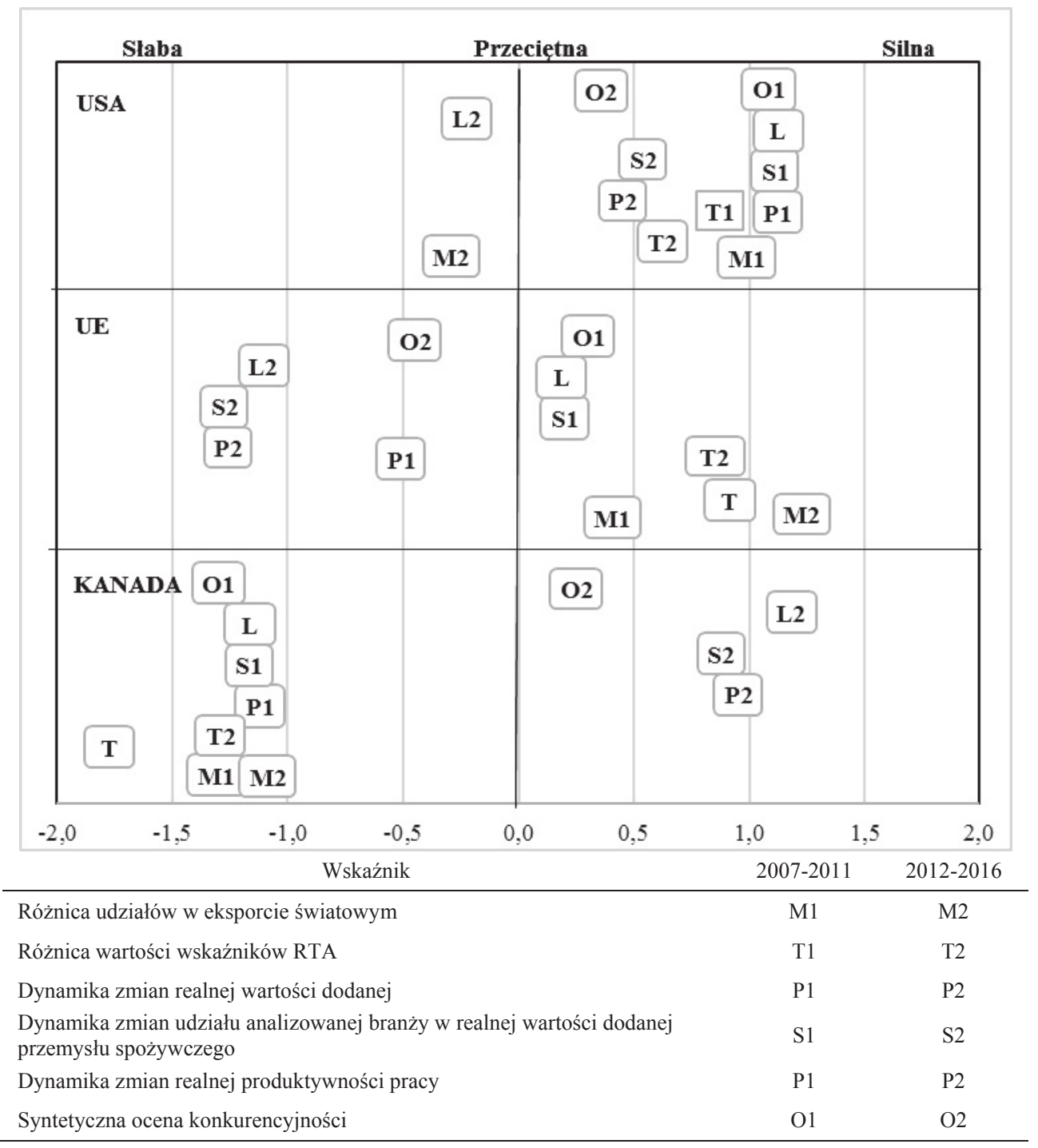

Rys. 1. Zmiany pozycji konkurencyjnej branży mleczarskiej krajów UE, USA i Kanady na rynku światowym w latach 2007-2011 i 2012-2016

Fig. 1. Developments in competitiveness of the EU, the US and Canadian dairy industry on the world market in 2007-2011 and 2012-2016

Źródło: (Agriculture and Agri-Food Canada 2018; Eurostat 2018; GATS 2018; The US Census Bureau 2018), obliczenia własne. 


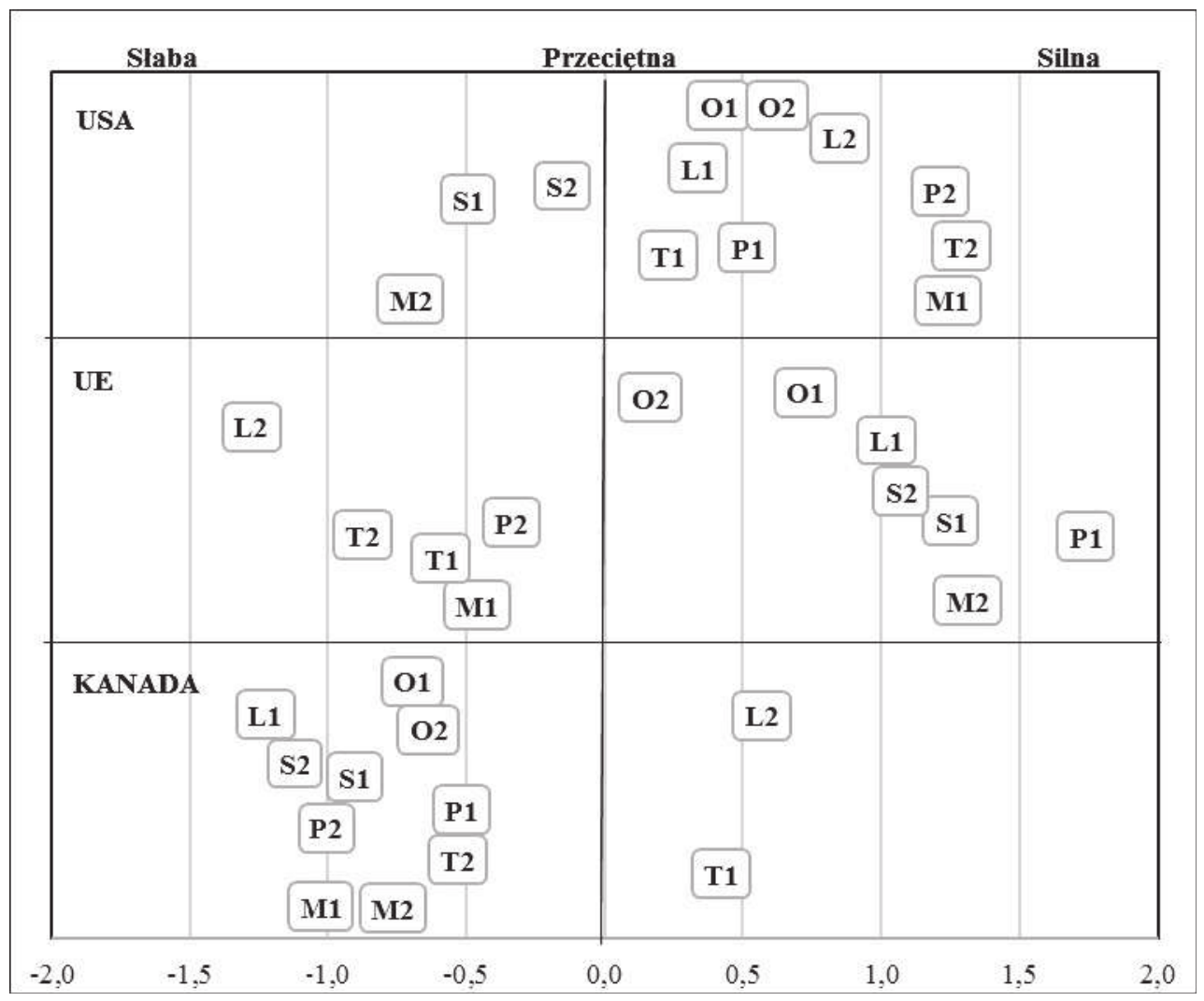

Rys. 2. Zmiany pozycji konkurencyjnej branży owocowo-warzywnej krajów UE, USA i Kanady na rynku światowym w latach 2007-2011 i 2012-2016

Fig. 2. Developments in competitiveness of the EU, the US and Canadian fruit and vegetable industry on the world market in 2007-2011 and 2012-2016

Objaśnienia: jak pod rysunkiem 1.

Źródło: (Agriculture and Agri-Food Canada 2018; Eurostat 2018; GATS 2018; The US Census Bureau 2018), obliczenia własne.

o tyle w przypadku UE ich poziom obniżał $\operatorname{się}^{6}$ na tyle, że notowane równolegle zwiększenie udziału w światowym eksporcie (M), mimo że istotne, nie było w stanie powstrzymać lub przynajmniej złagodzić osłabienia pozycji konkurencyjnej posiadanej w latach 2007-2011. Relatywnie najsłabszą pozycją konkurencyjną na rynku światowym charakteryzowało się kanadyjskie przetwórstwo owoców i warzyw. Notowany w latach 2007-2016 istotny wzrost wydajności pracy (L) w tej branży przemysłu spożywczego sprawiał co prawda, że w ujęciu całościowym pozycja konkurencyjna kanadyjskiego przemysłu owocowo-warzywnego była stabilna $(\mathrm{O})$, ale kształtowała się na poziomie poniżej przeciętnego.

${ }^{6}$ Badania Wijnandsa i Verhoog (2016) wskazują, że taką tendencję obserwowano już od 2003 roku. 


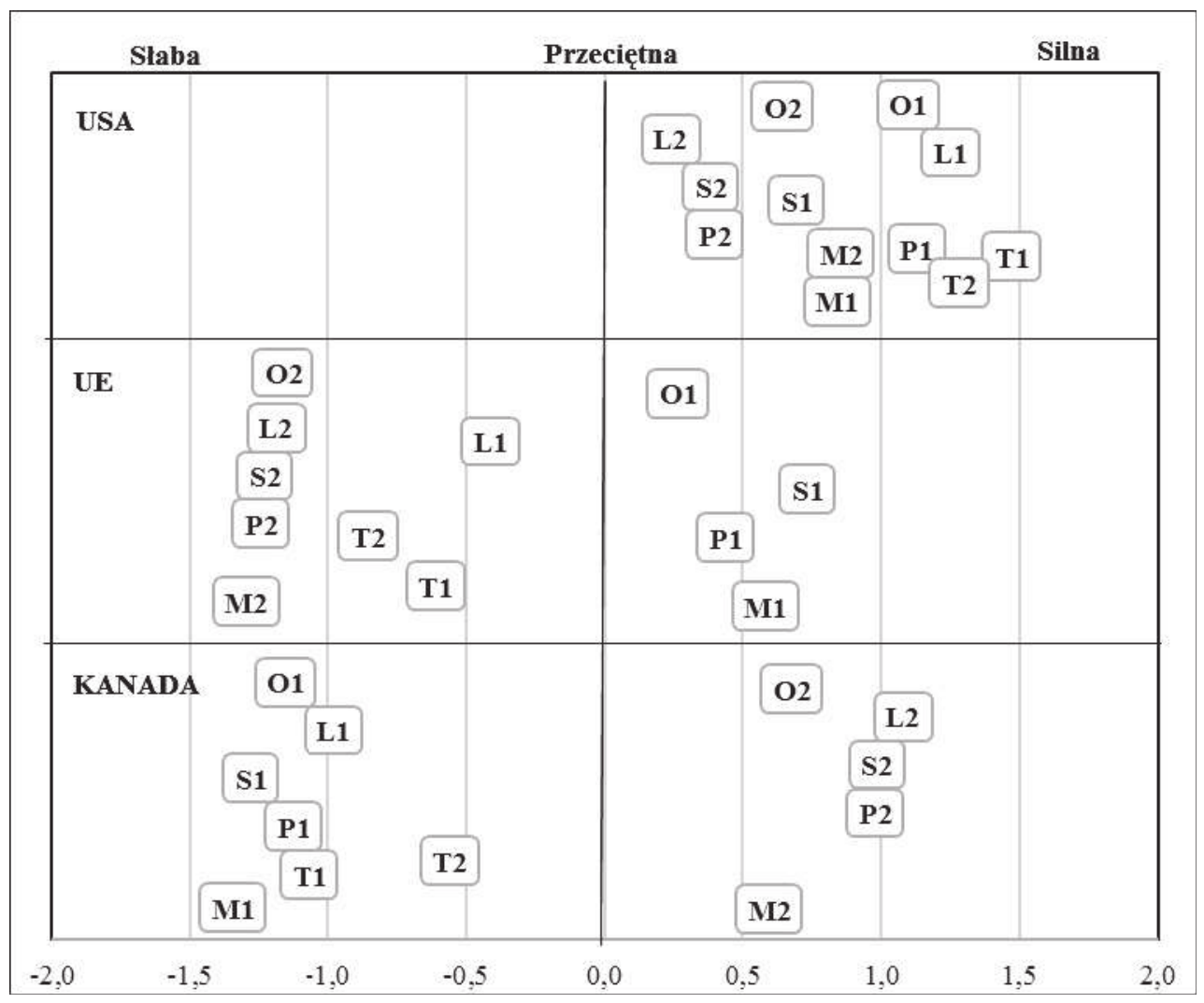

Rys. 3. Zmiany pozycji konkurencyjnej branży mięsnej krajów UE, USA i Kanady na rynku światowym w latach 2007-2011 i 2012-2016

Fig. 3. Developments in competitiveness of the EU, the US and Canadian meat industry on the world market in 2007-2011 and 2012-2016

Objaśnienia: jak pod rysunkiem 1.

Źródło: (Agriculture and Agri-Food Canada 2018; Eurostat 2018; GATS 2018; The US Census Bureau 2018), obliczenia własne.

Trudniejsza była sytuacja konkurencyjna analizowanych państw w dwóch pozostałych branżach przemysłu spożywczego, a szczególnie w przemyśle mięsnym, który we wszystkich badanych krajach był istotną branżą przetwórstwa spożywczego, przyczyniając się w około 20\% do wytwarzania realnej wartości dodanej (tab. 1). W latach 2012-2016 żaden z badanych krajów nie generował przewag komparatywnych w handlu światowym $(\mathrm{RTA}<0)$, a pomijając Kanadę (produktywność pracy w kanadyjskim przemyśle mięsnym była o około $20-30 \%$ niższa niż w innych branżach), produktywność pracy w przemyśle mięsnym w porównaniu $\mathrm{z}$ pozostałymi analizowanymi branżami była przynajmniej 2-krotnie niższa. W latach 2012-2016 najsłabszą w stosunku do konkurentów i znacząco gorszą niż w latach 2007-2011 pozycją konkurencyjną na rynku światowym (O) odznaczało się przetwórstwo mięsa w UE (rys. 3). W analizowanym okresie branża ta utraciła przewagi konkurencyjne, mierzone zarówno udziałem w rynku światowym (M), jak i wskaźnikami 
ekonomicznymi (P, S, L). Mimo zauważalnego osłabienia w latach 2012-2016 wobec 2007-2011, najsilniejszym konkurentem w eksporcie przetworów mięsnych pozostały USA, które jednak odczuwały w tym okresie coraz większą presję konkurencyjną ze strony przetwórców kanadyjskich, którzy nie posiadając jeszcze relatywnych przewag $\mathrm{w}$ handlu (T), zwiększali swój udział w eksporcie światowym (M) i umacniali pozycję ekonomiczną $(\mathrm{P}, \mathrm{S}, \mathrm{L})$, odzyskując $\mathrm{w}$ ten sposób relatywnie mocniejszą pozycję konkurencyjną posiadaną na rynku światowym w latach 2003-2007 (zob. Wijnands i Verhoog, 2016).

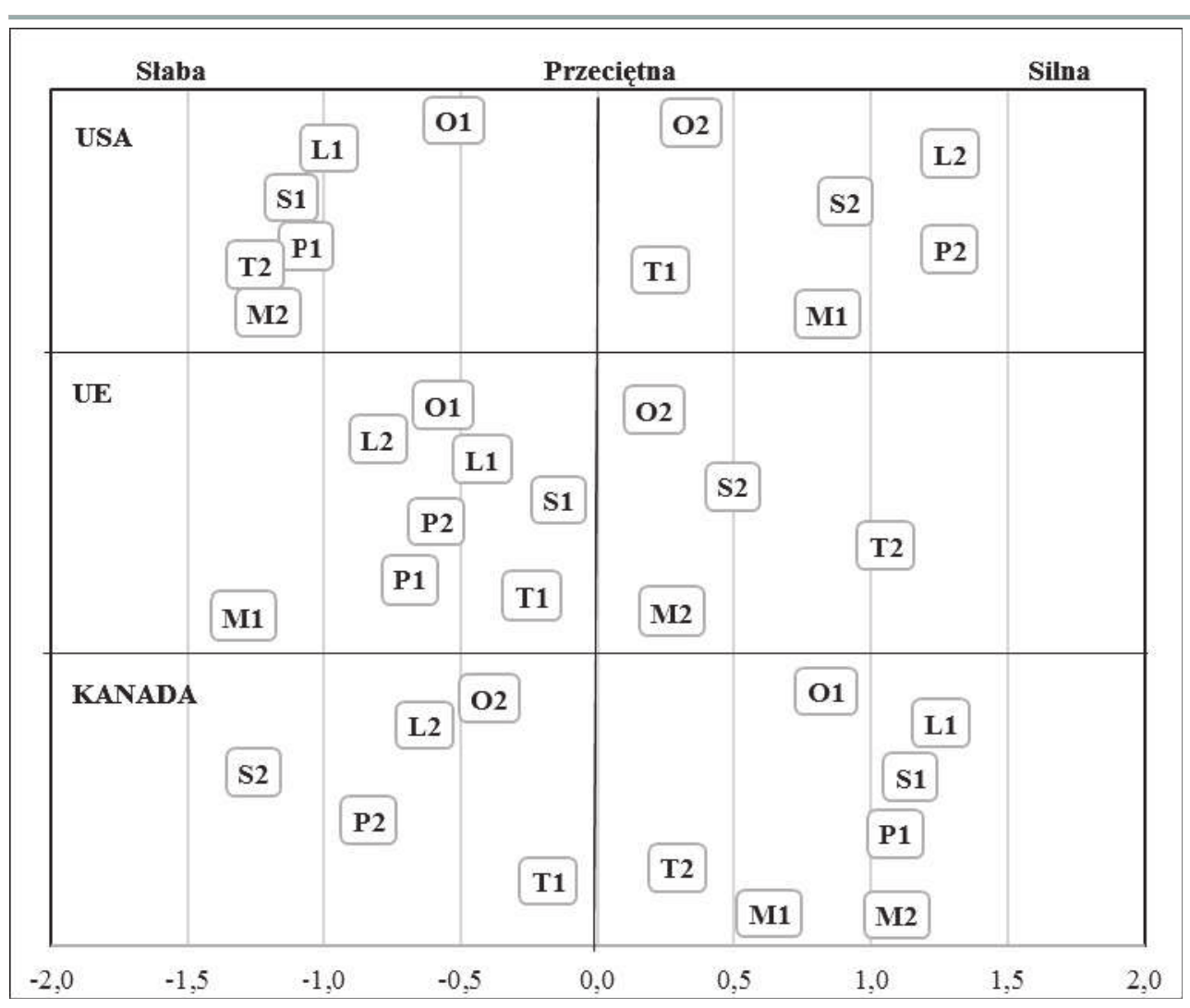

Rys. 4. Zmiany pozycji konkurencyjnej branży cukierniczej krajów UE, USA i Kanady na rynku światowym w latach 2007-2011 i 2012-2016

Fig. 4. Developments in competitiveness of the EU, the US and Canadian confectionery industry on the world market in 2007-2011 and 2012-2016

Objaśnienia: jak pod rysunkiem 1.

Źródło: (Agriculture and Agri-Food Canada 2018; Eurostat 2018; GATS 2018; The US Census Bureau 2018), obliczenia własne.

We wszystkich analizowanych gospodarkach, zbliżony około 5- lub 6-procentowy wkład w tworzenie realnej wartości dodanej przemysłu spożywczego miała branża cukiernicza (tab. 1). W latach 2012-2016 żaden z badanych krajów nie osiagał na rynku światowym przewag w handlu, ale stosunkowo najkorzystniejszą sytuacją konkurencyjną 
odznaczały się państwa UE, które notując obniżenie produktywności pracy (L), zarówno w porównaniu z okresem 2007-2011, jak i z konkurentami, dzięki poprawie pozostałych wskaźników, osiagnęły w latach 2012-2016 ponadprzeciętne przewagi konkurencyjne (O), nieco tylko ustępując pod tym względem USA (rys. 4). W tym kraju znaczącą poprawę wskaźników ekonomicznych niwelowała utrata pozycji rynkowej (M), osłabiając tym samym postęp w syntetycznej ocenie konkurencyjności (O). Przeciwne kierunkowo tendencje wystapily w kanadyjskiej branży cukierniczej. Utrata relatywnie silnej pozycji konkurencyjnej posiadanej $\mathrm{w}$ latach 2007-2011 wynikała z pogorszenia wskaźników ekonomicznych, którego nie rekompensował ani wzrost udziału w eksporcie światowym (M) ani umacnianie relatywnej przewagi w handlu (T).

\section{Podsumowanie}

Podsumowując przeprowadzone analizy można stwierdzić, że w latach 2012-2016 kraje UE generowały najwyższe przewagi komparatywne w eksporcie na rynek światowy produktów mleczarskich oraz owocowo-warzywnych, w zakresie których posiadały też największe spośród czterech analizowanych branż przemysłu spożywczego i większe niż konkurenci udziały w rynku światowym. Pozycję konkurencyjną tych branż osłabiała jednak stosunkowo niska realna produktywność pracy: 2-krotnie niższa niż w Kanadzie i 3-krotnie niższa niż w USA. Niepokojące jest odnotowane w porównaniu z okresem 2007-2011 pogorszenie pozycji konkurencyjnej wymienionych branż, wynikające przede wszystkim z osłabienia parametrów ekonomicznych, którego nie rekompensował w pełni wzrost udziałów w eksporcie światowym. W stosunkowo dobrej, a co więcej ulegającej poprawie w latach 2007-2016, sytuacji konkurencyjnej znajdował się unijny przemysł cukierniczy, który dzięki poprawie zarówno wskaźników ekonomicznych (z wyjątkiem wydajności pracy), jak i handlowych nieco tylko ustępował aktywnym na rynku światowym przetwórcom amerykańskim. W USA wzmocnieniu ulegała pozycja konkurencyjna analizowanych branż przetwórstwa roślinnego, a pogorszeniu - branż przetwórstwa zwierzęcego. Z wyją̨tkiem branży cukierniczej, największymi postępami w budowaniu trwałej pozycji konkurencyjnej na rynku światowym, mimo wciąż relatywnie najmniejszego na nim znaczenia, charakteryzowały się branże kanadyjskiego przemysłu spożywczego.

$\mathrm{Na}$ podstawie wykonanych analiz można zauważyć, że poprawa pozycji konkurencyjnej branż unijnego przemysłu spożywczego w większym stopniu była determinowana skalą aktywności w handlu światowym (rosnącymi udziałami w globalnym eksporcie), natomiast o przewagach konkurencyjnych przemysłu spożywczego USA i Kanady decydowały przewagi o charakterze ekonomicznym, zwiazzane $\mathrm{z}$ poprawa ekonomicznych wyników działalności przedsiębiorstw danej branży, jej udziału $\mathrm{w}$ tworzeniu realnej wartości dodanej przemysłu spożywczego oraz produktywności pracy. W tym kontekście, pozostając w zgodzie z tezami Krugmana (1994) i Fagerberga (1996), można uznać, że jednym z kluczowych czynników poprawy konkurencyjności międzynarodowej przemysłu spożywczego UE jest zwiększenie produktywności pracy. 


\section{Literatura}

Aiginger, K. (1998). A framework for evaluating the dynamic competitiveness of countries. Structural Change and Economic Dynamics, 9(2), 159-188. DOI: 10.1016/S0954-349X(97)00026-X.

Agriculture and Agri-Food Canada. Pobrane 2 czerwca 2018 z: http://www.agr.gc.ca/eng/industry-markets-andtrade/statistics-and-market-information/?id=1361289956531.

Devine, P. (1996). Competitiveness and the Objectives of Communities. W: P. Devine, Y. Katsoulacos, R. Sugden (red.) Competitiveness, Subsidiarity and Industrial Policy (s. 1-11). London, New York: Routledge.

EUROSTAT. Annual detailed enterprise statistics - industry and construction. Pobrane 2 czerwca 2018 z: http://ec.europa.eu/eurostat/data/database.

Fagerberg, J. (1996). Technology and Competitiveness. Oxford Review of Economic Policy, 12(3), 39-51. DOI: 10.1093/oxrep/12.3.39.

Fagerberg, J. (1997). Competitiveness, scale and R\&D. W: J. Fagerberg, P. Hansson, L. Lundberg, A. Melchior (red.) Technology and International Trade (s. 38-54). Cheltenham: Edward Elgar Publishing Limited.

Fagerberg, J., Knell, M., Srholec, M. (2004). The competitiveness of Nations: Economic Growth in the ECE Region. Economic Survey of Europe, 2, 51-66.

Fischer, Ch., Schornberg, S. (2007). Assessing the Competitiveness Situation of EU Food and Drink Manufacturing Industries: An Index-Based Approach. Agribusiness, 23(4), 473-495.

Frohberg, K., Hartmann, M. (1997). Comparing Measures of Competitiveness. Discussion Paper No. 2. Halle: IAMO.

Global Agricultural Trade System. Pobrane 6 czerwca 2018 z: https://apps.fas.usda.gov/gats/ExpressQuery1.aspx

Gradziuk, A., Kugiel, P. (red.). (2012). Polska w wielobiegunowym świecie. Szanse i perspektywy rozwoju stosunków Polski z głównymi mocarstwami wschodzacymi (Poland in a multipolar world. Opportunities and prospects for the development of Poland's relations with the main emerging powers). Raport Polskiego Instytutu Spraw Miedzynarodowych. Warszawa: PISM.

Jagiełło, E.M. (2008). Strategiczne budowanie konkurencyjności gospodarki (Strategic building of competitiveness of the economy). Warszawa: Wydawnictwo Poltext.

Kennedy, P.L., Harrison, R.W., Kalaitzandonakes, N.G., Peterson, H.Ch., Rindfuss, R.P. (1997). Perspectives on Evaluating Competitiveness in Agribusiness Industries. Agribusiness, 13(4), 385-392.

Kiwerska, J. (2018). Nowe problemy w stosunkach transatlantyckich (New problems in transatlantic relations). Biuletyn Instytutu Zachodniego, 340, 1-5.

Krugman, P. (1994). Competitiveness: A Dangerous Obsession. Foreign Affairs, 73(2), 28-44.

Latruffe, L. (2010). Competitiveness, Productivity and Efficiency in the Agricultural and Agri-Food Sectors. OECD Food, Agriculture and Fisheries Working Papers No. 30. Paris: OECD Publishing.

Lubiński, M. (1995). Konkurencyjność gospodarki: pojecie i sposób mierzenia (Competitiveness of the economy: the concept and measurement). W: M. Lubiński, T. Smuga (red.) Międzynarodowa konkurencyjność gospodarki Polski - uwarunkowania i perspektywy (International competitiveness of the Polish economy determinants and prospects). Raporty - Studia nad konkurencyjnością. Warszawa: Instytut Rozwoju i Studiów Strategicznych.

Milczarek, D. (2008). Stosunki transatlantyckie w sferze polityki zagranicznej i bezpieczeństwa: kontynuacja czy przełom? Polski punkt widzenia (Transatlantic relations in the area of foreign and security policy: follow-up or break-point? Polish perspective). Studia Europejskie, 2, 31-57.

Nassif, A., Feijo C., Araújo, E. (2016). The BRICS's Economic Growth Performance before and after the International Financial Crisis. International Journal of Political Economy, 45(4), 294-314. DOI: $10.1080 / 08911916.2016 .1270083$

Nayyar, D. (2016). BRICS, developing countries and global governance. Third World Quarterly, 37(4), $575-591$. DOI: $10.1080 / 01436597.2015 .1116365$.

Pawlak, K. (2013). Międzynarodowa zdolność konkurencyjna sektora rolno-spożywczego krajów Unii Europejskiej (International competitive capacity of the agri-food sector in the European Union countries). Rozprawy Naukowe, 448. Poznań: Wydawnictwo Uniwersytetu Przyrodniczego w Poznaniu.

Pitts, E., Lagnevik, M. (1998). What determines food industry competitiveness? W: W.B. Traill, E. Pitts (red.) Competitiveness in the food industry (s. 1-34). London: Blackie Academic \& Professional.

Poczta, W., Beba, P. (2014). Rola przemysłu spożywczego w gospodarkach krajów UE (The role of the food industry in European Union countries). ZN SGGW Problemy Rolnictwa Światowego, 14(3), 158-167.

Porter, M.E. (1990). The Competitive Advantage of Nations. New York: The Free Press, A Division of Macmillan Inc.

President's Commission on Industrial Competitiveness (1985). Global Competition: The New Reality. Washington D.C.: U.S. Government Printing Office. 
Scott, L., Vollrath, T. (1992). Global Competitive Advantages and Overall Bilateral Complementarity in Agriculture: A Statistical Review. Washington: Economic Research Service, U.S. Department of Agriculture.

Siddiqui, K. (2016). Will the Growth of the BRICs Cause a Shift in the Global Balance of Economic Power in the 21st Century? International Journal of Political Economy, 45(4), 315-338. DOI: 10.1080/08911916.2016.1270084.

Siggel, E. (2006). International competitiveness and comparative advantage: A survey and a proposal for measurement. Journal of Industry, Competition and Trade, 6(2), 137-159. DOI:10.1007/s10842-006-8430-

Singh, A. (1977). UK industry and the world economy: a case of de-industrialisation. Cambridge Journal of Economics, 1(2), 113-136. DOI: 10.1093/oxfordjournals.cje.a035354.

Sporek, K., Czech, K. (red.). (2015). Państwa grupy BRICS i ich znaczenie we współczesnej gospodarce światowej (BRICS countries and their importance in the contemporary global economy). Katowice: Wydawnictwo Uniwersytetu Ekonomicznego w Katowicach.

Tereszczuk, M. (2016). Ocena pozycji konkurencyjnej przemysłu spożywczego w Polsce na tle wybranych państw Unii Europejskiej (An assessment of the competitive position of the food industry in Poland against selected European Union countries). W: I. Szczepaniak (red.) Konkurencyjność polskich producentów żywności i jej determinanty (2) (Competitiveness of Polish food producers and its determinants (2)). Raport PW 2015$2019 \mathrm{Nr}$ 38. Warszawa: IERiGŻ-PIB.

The BRICS Report. A Study of Brazil, Russia, India, China, and South Africa with special focus on synergies and complementarities (2012). New Delhi: Oxford University Press.

The US Census Bureau. Annual Survey of Manufactures. Pobrane 9 czerwca 2018 z: http://www.census.gov/ programs-surveys/asm/data/tables.html.

Van Duren, E., Martin, L., Westgren, R. (1991). Assessing the Competitiveness of Canada's Agrifood Industry. Canadian Journal of Agricultural Economics, 39(4), 727-738. DOI: 10.1111/j.1744-7976.1991.tb03630.x.

Wijnands, J., van Berkum, S., Verhoog, D. (2015). Measuring Competitiveness of Agro-Food Industries: The Swiss Case. OECD Food, Agriculture and Fisheries Papers No. 88. Paris: OECD Publishing.

Wijnands, J.H.M., Bremmers, H.J., van der Meulen, B.M.J., Poppe, K.J. (2008). An economic and legal assessment of the EU food industry's competitiveness. Agribusiness, 24(4), 417-439.

Wijnands, J.H.M., van der Meulen, B.M.J., Poppe, K.J. (2006). Competitiveness of the European food industry. An economic and legal assessment 2007. European Commission Project No. 30777. The Hague: LEI.

Wijnands, J.H.M., Verhoog, D. (2016). Competitiveness of the EU food industry. Ex-post assessment of trade performance embedded in international economic theory. LEI Report 2016-018. Wageningen: LEI Wageningen UR (University \& Research Centre).

Zawiślińska, I. (2003). Gospodarka Kanady przełomu wieków. Międzynarodowa pozycja konkurencyjna (Canadian economy at the turn of the century. International competitive position). Warszawa: Oficyna Wydawnicza SGH.

Do cytowania / For citation:

Pawlak K. (2018). Zdolność konkurencyjna przemysłu spożywczego krajów UE, USA i Kanady na rynku światowym. Problemy Rolnictwa Światowego, 18(3), 248-261; DOI: $10.22630 /$ PRS.2018.18.3.83

Pawlak K. (2018). Competitive Capacity of the EU, the US and Canadian Food Industry on the World Market (in Polish). Problems of World Agriculture, 18(3), 248-261; DOI:10.22630/PRS.2018.18.3.83 